\title{
ANAESTHETIC MANAGEMENT OF INFANTS UNDERGOING PROFOUND HYPOTHERMIA FOR SURGICAL CORRECTION OF CONGENITAL HEART DEFECTS
}

\author{
D.J. STEWARD, M.B., F.R.C.P.(c), I.A. SLOAN, M.D., F.R.C.P.(c), \\ AND A.E. JohnSTON, M.D., F.R.C.P. (c) ${ }^{\circ}$
}

INTRA-CARDIAC SURGERY in neonates and infants by conventional cardiopulmonary bypass has resulted in high mortality and morbidity rates. ${ }^{1}$ The use of alternative methods in this age group has, therefore, been extensively investigated and techniques utilizing profound hypothermia with total circulatory arrest for periods up to 90 minutes have been advocated.1,2 The advantages of such a method include:

1. The heart is exsanguinated and relaxed during the surgical repair allowing optimal conditions for delicate surgery in a small heart.

2. There are no canulae to limit the surgical field during intra-cardiac repair.

3. The duration of total body perfusion can be limited to a minimum.

Profound hypothermia for cardiac surgery was introduced by Drew in 1959 using bypass cooling with the lungs as the oxygenator. ${ }^{3}$ Horiuchi in 1963 used surface cooling and rewarming to achieve profound hypothermia for infant cardiac surgery. ${ }^{4}$ Hikasi combined surface and bypass cooling and rewarming in the infant age group. ${ }^{5}$

Numerous teams are now employing various combinations of surface and bypass cooling to achieve deep hypothermia for correction of congenital heart disease in very young infants. ${ }^{1,2,6}$

At The Hospital for Sick Children, Toronto, 25 infants were operated upon under profound hypothermia during 1972 and early 1973. The youngest patient was 11 days and the oldest 48 months. All the patients weighed under $11 \mathrm{Kg}$ and the smallest was $3.24 \mathrm{Kg}$. The cardiac diagnoses are listed in Table I. The miscellaneous group includes two cases of truncus arteriosis, two of A.V. communis, one of mitral incompetence, one A.P. window, and two cases of combinations of V.S.D., A.S.D. and pulmonary stenosis. One patient was found at operation to have a single ventricle.

All the patients were classified in A.S.A. risk groups 4 and 5 . All but two cases were on digitalis therapy which was continued up to the time of operation in order to control or improve varying degrees of cardiac failure. Ten cases had also been treated with diuretics over various periods. One patient was on controlled ventilation pre-operatively, having had a recent cardiac arrest.

\footnotetext{
Department of Anaesthesia, The Hospital for Sick Children, Toronto, Ontario. Department of Anaesthesia, University of Toronto.
}

Canad. Anaesth. Soc. J., vol. 21, no. 1, January 1974 
TABLE I

The Hospital for Sick Children, TORonto

Profound Hy POTHERMIA 1972-73

\begin{tabular}{ccc}
\hline & No. of Cases & Deaths \\
\hline Ventricular Septal Defect & 5 & $(0)$ \\
Total Anomalous Pulmonary Venous Drainage & 4 & $(1)$ \\
Transposition of Great Arteries & 7 & $(3)$ \\
Miscellaneous & 9 & $(6)$ \\
Total & 25 & $(10)$ \\
\hline
\end{tabular}

\section{Anaesthetic Management}

The patients in the described series fall into two groups:

Group I were cooled by surface cooling to $25-28^{\circ} \mathrm{C}$ prior to bloodstream cooling to $16^{\circ} \mathrm{C}$ (oesophageal) (16 patients).

Gnoup II were cooled by surface cooling to $31-32^{\circ} \mathrm{C}$ - thence to $16^{\circ} \mathrm{C}$ (oesophageal) by bloodstream cooling ( 9 patients).

Premedication consisted of intramuscular atropine $0.02 \mathrm{mg} / \mathrm{Kg}$ in most cases; in some morphine $0.1 \mathrm{mg} / \mathrm{Kg}$ intramuscular and/or pentobarbitone $0.2 \mathrm{mg} / \mathrm{Kg}$ P.R. was added.

The anaesthetic technique consisted of nitrous oxide, 50 per cent in oxygen; halothane $0.5-1.0$ per cent if tolerated, with curare or pancuronium. In those cases which would not tolerate halothane, intravenous meperidine was used to supplement nitrous oxide. Controlled ventilation was established to maintain a $\mathrm{PaCO}_{2}$ of 40 torr. Electrocardiogram and electroencephalogram were monitored, arterial and venous catheters inserted for pressure monitoring and sampling, and temperatures were measured in the naso-pharynx, oesophagus and rectum. A urinary catheter was inserted and urine flow measured.

Surface cooling was performed by placing the child on a cooling blanket and covering the body surface with small plastic bags of crushed, melting ice. Cooling was discontinued when the oesophageal temperature was 2 degrees above the desired temperature. During surface cooling 5 per cent carbon dioxide was added to the inspired gases when the patient's temperature was below $34^{\circ} \mathrm{C}$ (oesophageal). The mean arterial carbon dioxide tension which resulted at various oesophageal temperatures with 5 per cent $\mathrm{CO}_{2}$ added and maintaining constant ventilation is shown in Table II. The addition of carbon dioxide during hypothermia improves tissue oxygenation by maintaining peripheral and cerebral vasodilation and preventing a major shift in the haemoglobin/oxygen dissociation curve. Avoidance of respiratory alkalosis may also minimize cardiac arrhythmias. Patients with a high haematocrit were given plasma during surface cooling and in the interval until cardio-pulmonary bypass was initiated.

When the desired temperature was reached the chest was opened, heparin $2 \mathrm{mg} / \mathrm{Kg}$ administered, and cannulations performed. The patient was then cooled on partial cardio-pulmonary bypass using a haemodilution technique described elsewhere. ${ }^{8,9}$ During cooling the temperature gradient between oesophageal 
TABLE II

Mean $\mathrm{PCO}_{2}{ }^{*}$ at Various Temperatures with $5 \% \mathrm{~F}_{\mathrm{I}} \mathrm{CO}_{2}$

\begin{tabular}{lllll}
\hline \hline Temperature: & $34^{\circ}$ & $32^{\circ}$ & $28^{\circ}$ & $25^{\circ}$ \\
& $(1$ case $)$ & $(3$ cases $)$ & $(7$ cases $)$ & $(4$ cases $)$ \\
& $60 \mathrm{~mm} / \mathrm{Hg}$ & $39 \mathrm{~mm} / \mathrm{Hg}$ & $38 \mathrm{~mm} / \mathrm{Hg}$ & $33 \mathrm{~mm} / \mathrm{Hg}$ \\
\hline
\end{tabular}

${ }^{*}$ All acid-base and blood gas results are reported after correction to the existing oesophageal temperature.

TABLE III

Cooling Bypass Time to $16^{\circ} \mathrm{C}$ (oesophageal)

\begin{tabular}{lll}
\hline & Group I & Group II \\
\hline Surface Cooling: & $<30^{\circ}$ & $>30^{\circ}$ \\
& $(16$ cases $)$ & $(9$ cases $)$ \\
& 8 minutes & 14 minutes \\
\hline
\end{tabular}

TABLE IV

Toral Bypass Time (25 cases)

\begin{tabular}{lll}
\hline & Group I & Group II \\
\hline Surface Cooling: & $<30^{\circ}$ & $>30^{\circ}$ \\
& $(16$ cases $)$ & $(9$ cases $)$ \\
& 26 minutes & 38 minutes \\
\hline
\end{tabular}

temperature and the output from the pump was maintained at less than $10^{\circ} \mathrm{C}$. When the oesophageal temperature reached $16^{\circ} \mathrm{C}$ the output from the pump was maintained at that level until the rectal temperature approached $20^{\circ} \mathrm{C}$. Cardiopulmonary bypass was then discontinued, the venous lines kept open and the blood drained into the oxygenator. Venous cannulae were then removed and the intra-cardiac repair commenced. The duration of the cooling pump run in each of the two groups is shown in Table III.

The period of total circulatory arrest varied from 22 to 85 minutes, with a mean duration of 58 minutes. During this period the lungs were maintained inflated with air at a pressure of $5 \mathrm{~cm}$ water.

Following intra-cardiac repair the venous cannulae were replaced, air was removed from the heart and cardio-pulmonary bypass was reinstituted, the blood having been previously warmed to $10^{\circ} \mathrm{C}$ above the patient's oesophageal temperature. Rewarming was continued until the oesophageal temperature reached $37^{\circ} \mathrm{C}$ and the rectal temperature was above $34^{\circ} \mathrm{C}$. Warming blankets were also employed at this stage, their temperature being set at $10^{\circ} \mathrm{C}$ above oesophageal (to maximum of $40^{\circ} \mathrm{C}$ ). The total period of cardiopulmonary bypass in the two groups is shown in Table IV.

During and immediately after rewarming a severe metabolic acidosis is frequently seen; however, the results of studies done on 11 of these cases ${ }^{8}$ confirm a previous report ${ }^{2}$ that this tends to be self-correcting. Hence, provided the clinical status allows, sodium bicarbonate is withheld to avoid subsequent metabolic alkalosis. 


\section{Post-Operative Care}

At the end of the operation a decision must be made whether continuation of controlled ventilation is required. This is based on a knowledge of the type of lesion which has been corrected, the intra-operative course and the clinical condition of the patient, together with blood gas and acid-base studies. Six of our patients were extubated in the operating room and allowed to breathe spontaneously. In the other cases a nasotracheal tube was left in situ and 11 were ventilated for 24 hours or more. The remainder were treated with continuous positive airway pressure for periods from 3 hours to 48 hours.

Blood losses occurring post-operatively were measured and replaced with whole blood. Five per cent glucose with 0.2 normal saline was administered intravenously at the rate of $2 \mathrm{ml} / \mathrm{Kg} / \mathrm{hr}$. This is approximately one half the normal fluid maintenance requirements. Furosemide (Lasix $\left.{ }^{\circledR}\right)^{\circ}$ was administered when needed to maintain urine output and to prevent fluid retention following cardiopulmonary bypass with haemodilution.

\section{COMPLICATIONS: INTRA-OPERATIVE}

\section{Ventricular Fibrillation}

Ventricular fibrillation occurred in six patients surface cooled to below $30^{\circ} \mathrm{C}$. It did not occur in any case above $30^{\circ} \mathrm{C}$. In every case, ventricular fibrillation occurred without any prior warning arrhythmia, during initial exposure of the heart. Surgical manipulation was considered a possible factor in two cases. Only one of these six patients was anaesthetized with halothane; the other five became markedly hypotensive with halothane, and had been changed to a nitrous oxide, narcotic, curare regime. Blood gases taken shortly before the onset of fibrillation failed to demonstrate any common pattern in these patients. All were well oxygenated (mean $\mathrm{PaO}_{2}=195$, Range 107-270 torr) and the $\mathrm{PaCO}_{2}$ was in the physiological range when corrected for the degree of hypothermia (mean $\mathrm{PaCO}_{2}=42.9$ torr, range $35-51$ torr). These patients were, however, all on digitalis and had shown potassium values in the low range of normal (mean $3.4 \mathrm{mEq} / \mathrm{L}$, range $2.3-4.1 \mathrm{mEq} / \mathrm{L})$. Four patients were successfully defibrillated; one developed asystole and required pacing; one case had persistent ventricular fibrillation and was supported by internal cardiac massage until cardio-pulmonary bypass could be established.

\section{Heart Block}

Six patients developed third degree heart block following the intra-cardiac repair and required pacing. Two of these resumed normal sinus rhythm within 24 hours.

\section{Complications: Post-Operative}

\section{Pulmonary Complications}

Major pulmonary complications occurred in five cases, including one patient who required bronchoscopy for atelectasis of the left lung and four patients with

-Furosemide (Lasix $($ ) : Hoeschst Pharmaceuticals, Montreal. 
lobar atelectasis treated by intensive physiotherapy. In several other cases it was noted that tracheobronchial secretions seemed unusually tenacious and these patients required very careful post-operative respiratory care.

\section{Cardiac Complications}

"Low cardiac output syndrome" occurred in four patients and was treated with isoproterenol. Three of these patients subsequently developed renal failure and died. Apart from the patients already noted to have third degree heart block during operation, no further patients developed conduction abnormalities in the postoperative period.

\section{Metabolic Problems}

Early in the series two patients developed significant hypokalaemia postoperatively. The majority of the other patients had serum potassium levels in the low normal range during the first 24 hours, despite routine administration of 2 rnEq of potassium chloride per Kg per 24 hours. $^{8}$ One patient developed neurological problems in the late post-operative period, having been apparently neurologically intact after operation. This patient had a history of previous seizures, subsequently became comatose and died six weeks post-operatively. Investigation in this patient showed a significantly low serum magnesium among other electroJyte abnormalities.

\section{Discussion}

The use of profound hypothermia in cardiac surgery has waxed and waned in popularity. The series reported here indicates that in a group of patients of acceptable surgical risk (uncomplicated V.S.D.) very good results can be obtained by these methods. The overall mortality rate in this series reflects the very high surgical risk in many of the severely ill patients involved.

On the basis of the experience gained from these cases some observations are indicated. One question that has been posed is the value of surface cooling prior to cooling on cardiopulmonary bypass. It has been stated that prior surface cooling results in smaller temperature gradients throughout the body and a more even cooling, in addition to decreasing the necessary time of total body perfusion. ${ }^{1}$ In the patients described above, surface cooling to 25 to $28^{\circ} \mathrm{C}$ decreased the required cooling perfusion time (to $16^{\circ} \mathrm{C}$ oesophageal) by an average of six minutes. It is also noteworthy that the rewarming time in these same patients was shorter by a mean of six minutes. This could indicate that there had been less alteration of distribution of blood flow in these patients due to capillary shutdown. There was no significant difference in the average weight in the two groups.

The measurement of body temperature in small babies requires special considerations. In several babies in our series it was observed that the rectal temperature fell more rapidly than the oesophageal and nasopharyngeal temperatures during cooling, as has been noted by Brown et al. ${ }^{6}$ This is due to the proximity of the rectal probe to the cooling blanket and to the lack of insulating intervening tissue and is an artifact which can be avoided by placing a pad under the buttocks. 
Otherwise, the rectal temperature must not be interpreted as a true index of "core temperature".

Cooling below $30^{\circ} \mathrm{C}$ introduces the hazard of ventricular fibrillation, which occurred in six of our patients. Various methods were used to minimize this risk in reported series. Deep ether anaesthesia has been used ${ }^{7}$ however, this is not considered compatible with the extensive use of electrical and electronic apparatus necessary in these cases. Halothane has been employed with success as an alternative to ether. ${ }^{1}$ Methoxyflurane has also been used with some success. ${ }^{10}$ Many cases with marginal cardio-vascular reserve will not, however, tolerate, the potent inhalation agents. Certainly the majority of patients in our series in whom ventricular fibrillation was a problem were receiving nitrous oxide, narcotic, curare anaesthesia. Other factors possibly involved in these serious arrhythmias are digitalis therapy and low levels of serum potassium. A fall in serum potassium has been noted to occur with the induction of hypothermia ${ }^{6,8}$ and could be a significant factor with some patients, particularly those on digitalis. The administration of potassium supplements during cooling has been suggested to minimize this danger. ${ }^{8}$ The hypothermic patient must certainly be handled gently and unnecessary manipulation avoided.

The post-operative complications in this series were not considered different from those encountered in any group of patients of this age following major cardiovascular surgery. There were no cases of neurological impairment which could be associated with the technique of profound hypothermia. There were no cases in which post-operative haemostasis was a problem; this may be related to the short total period of cardio-pulmonary bypass.

Post-operative acid-base and electrolyte imbalance following the haemodilution bypass technique used in this series are reviewed by Johnston et al. ${ }^{9}$ Increased post-operative potassium and magnesium supplements are recommended for $24-48$ hours in these infants.

\section{SummaRY}

A combination of surface and bypass cooling has been utilised to induce profound hypothermia for the correction of congenital heart defects in a series of twenty-five infants. The anaesthetic management of these cases is described and discussed.

\section{RÉSUMÉ}

Nous avons utilisé une association de refroidissements de surface et par circulation extracorporelle pour produire une hypothermie profonde pour la correction de défectuosités cardiaques congénitales dans une série de 25 enfants. Nous décrivons et discutons la conduite de l'anesthésie de ces cas.

L'usage de l'hypothermie profonde pour la chirurgie cardiaque a subi des hausses et des baisses de popularité. Les cas que nous étudions ici font voir que des malades d'un risque opératoire acceptable (défectuosités non compliquées du système vasculaire) peuvent être opérés avec de bons résultats en utilisant 
ces méthodes. Le taux de mortalité totale de cette série de cas dénote le risque opératoire élevé chez plusieurs enfants très malades opérés.

A la suite de l'expérience acquise par ces cas, voici quelques observations. La question qui s'est posée: quelle est la valeur du refroidissement périphérique avant le refroidissement par circulation extracorporelle. Il a été établi que le refroidissement périphérique préalable produit de plus petites différences de température dans l'organisme et un refroidissement plus égal en plus de diminuer le temps requis de la perfusion totale.

Chez les malades ci-haut décrits, le refroidissement (à $16^{\circ} \mathrm{C}$ dans l'œsophage) d'une moyenne de 6 minutes. A noter également que le temps requis pour le réchauffement chez ces mêmes malades a été abrégé d'une moyenne de 6 minutes.

Cela pourrait indiquer qu'il y a eu moins de modifications dans la distribution du courant sanguin chez ces malades à cause de la fermature capillaire. Il n'y avait pas de différence dans le poids moyen des malades des deux groupes.

La mesure de la température chez les petits poupons exige une attention spéciale. Chez plusieurs bébés de nos malades, nous avons observé que la température rectale baisse plus rapidement que la température œsophagienne et nasopharyngienne, comme l'ont observé Brown et al. ${ }^{6}$ Cela est dû à la proximité du thermomètre rectal du matelas refroidissant et au manque de tissus isolants et cela peut être corrigé facilement en plaçant un coussinnet sous les fesses. Autrement, la température rectale ne doit pas être interprétée comme un indicateur précis de la température.

Un refroidissement au-dessous de $30^{\circ} \mathrm{C}$ provoque le risque de fibrillation ventriculaire, ce qui est survenu chez six de nos malades. Nous avons utilisé des méthodes variées pour amoindrir ce risque chez nos malades. Nous avons employé une anesthésie profonde à l'éther; toutefois, cela n'était pas compatible avec le grand nombre d'appareils électriques et électroniques nécessaites pour opérer ces malades. Comme substitut de l'éther, nous avons employé l'halothane. Nous avons également employé avec succès le méthoxyflurane. Cependant, plusieurs malades dont les réserves cardiovasculaires sont limitées ne peuvent pas tolérer les agents puissants par inhalation. De façon certaine, la majorité de nos malades chez qui la fibrillation ventriculaire nous a causé des problèmes recevaient du protoxyde d'azote, des narcotiques et des curares. Parmi les autres facteurs impliqués dans ces cas d'arythmies sérieuses il faut retenir la digitale et les taux bas de potassium sérique. Nous avons noté une diminution du potassium sérique au cours de l'induction de l'hypothermie; ${ }^{6.8}$ cela pourrait devenir un facteur chez certains malades, particulièrement ceux qui prennent de la digitale. Pour diminuer ce danger, nous suggérons d'administrer du potassium durant le refroidissement. Le malade en hypothermie doit être bougé avec délicatesse et le moins possible.

Les complications post-opératoires de ce groupe ressemblent à celles de tout autre groupe du même âge après de la chirurgie cardio-vasculaire ne peut être attribué à cette technique d'hypothermie profonde. Aucun problème d'homéostase au cours des suites opératoires ne s'est posé; ce problème se pose pour la courte période complète de la circulation extracorporelle.

Johnston et al. font l'étude de l'équilibre acide-base et de l'équilibre électro- 
lytique à la suite de l'hémodilution de l'amorce de la circulation extracorporelle de ces malades. ${ }^{9}$ Chez ces enfants, durant les $24-48$ heures suivant l'opération, il est à conseiller d'augmenter le potassium et le magnésium sériques.

\section{REFERENCES}

1. Bafratt-Boyes, B.G., Simpson, M., \& Neutz, J.M. Intra-cardiac surgery in neonates and infants using deep hypothermia with surface cooling and limited cardio-pulmonary bypass. Suppl. I to circulation Vol. XLIII and Vol. XLV, May 1971, pp. 125-130.

2. Belsey, R.H.R., Dowlatshah, K., Green, G., \& Skinner, D.B. Profound hypothermia in cardiac surgery. J. Thoracic \& Cardiov. Surgery 56: 497-506 (1968).

3. Drew, C.E. \& Anderson, I.M. Profound hypothermia in cardiac surgery. Lancet I, 748750 (1959).

4. Honiuchi, T., Koyamada, K., Matamo, I., et al. Radical operation for ventricular septal defect in infancy. J. Thoracic \& Cardiovascular Surgery 46: 180-190 (1963).

5. Hikasa, Y., Shirotani, H., Datomuna, K., et al. Open-heart surgery in infants with an aid of hypothermic anaesthesia. Arch. for Japanische Chirurgie 36: 495-508 (1967).

6. Brown, T.C.K., Clarke, C.P., Shanahan, E.A., McKie, B.D., Woon, H.M., \& Thorp, E.A. The management of infants for cardiac surgery under deep hypothermia. Anaesthesia and Intensive Care, 1: 137-140 (1972).

7. Mohri, H., Dillard, D.H., Crawford, E.H., Martin, W.E., \& Merending, K.A. Method of surface induced deep hypothermia for open heart surgery in infants. J. Thoracic \& Cardiovascular Surgery 58: 262-270 (1969).

8. Abrahams, N., Johnston, A.E., Taylor, J., Nisbet, H.I.A., \& Radde, I.C. A Comparison of the effects of two haemodiluents on monovalent and divalent cations in children undergoing cardiopulmonary bypass and open heart surgery. Can. Anaes. Soc. J. 20: 153-169 (1973).

9. Johnston, A.E., Radde, I.C., Steward, D.J., \& Tayloh, J. Acid-base and electrolyte changes in infants undergoing surgical correction of congenital heart defects. C.A.S.J. $21: 23-45$.

10. Nisbet, H.I.A. \& Pelton, D.A. Personal communication. Unpublished data. 